\title{
Analysis of Formation Mechanism of Revisit Intention: Data from East China
}

\author{
Huamin Li \\ Ningbo Institute of Technology, Zhejiang University \\ Ningbo, China \\ huaminlee@163.com
}

\begin{abstract}
The paper discusses the factors of revisit intention, and constructs an Extended Model of TPB which contains the variables of attitude, customer's value etc. Based upon the literature review, the paper constructs the measurement of these factors. The structured survey is adapted to encompass four different destination types and the data is analyzed through SEM to research the formation mechanism of revisit intention. The results demonstrate that subjective norm, behavior control perception, attitude, past behavior, destination image, value of tourists and other variables have significant influence on revisit intention. Attitude and customer's value are the mediator variables in the mode, and they also have significant influence on revisit intention. Other variables have significant effects or have indirect influence on revisit intention.
\end{abstract}

Keywords- revisit intention; destination; formation mechanism; tourist value; Theory of Planned Behavior; extended model

\section{INTRODUCTION}

The research on destination revisit intention is rooted in the study of tourist behavior. Tourist behavior intention is a prime condition of tourist behavior, the core of which is purchasing decision. However, there are differences between the tourists' decision-making and decision-making on other products, since the tourists can't experience travel products before purchasing them. Therefore, the tourist's decision always contains greater risks and needs for more extensive information search. Decision-making must be done solely by relying on tourist subjective judgments of whether the destination meets their needs or not. So tourist behavior always goes through a complex mechanism, especially when choosing a destination. Destination revisit intention has been viewed as an important research topic both in academia and the tourism industry (Feng 2007).

In the Theory of Planned Behavior, Ajzen(1991) defined behavior intention as an intention trying to execute some specific activity. Behavior intention cannot predict the degree of realization of the target, even if some factors are beyond control, but it can predict that the individual's willingness to execute some specific action. The theory of Planned Behavior (TPB) is the most common-used theory of behavior. It was found that the prediction of kinds of tourism behavior of TPB is between 0.37 and 0.63 , and which of mountain tourism is the highest among them (Ajzen and Driver 1992). In the theory of planned behavior, intention to perform a behavior is determined not only by attitude toward the behavior, but also by perceived social pressure (i.e., subjective norm) and by perceived control over the behavior (de Vries et al. 1988).
Kerner and Kalinski (2002) have used TPB to study the attitude, belief, behavior control and intention of attending tourism activities of senior high school students. The results demonstrated promoting active attitude is beneficial for the perceived behavioral control of tourism and tourism intention. These studies have demonstrated that TPB's high prediction . Also, the empirical research of many scholars demonstrated that Subjective Norm and Perceived behavioral control has a mediating effect on behavior intention through attitude (Kerner and Kalinski 2002; Ajzen and Driver 1992), while past behavior also entered the model as an important variable for prediction of future behavior intention (Bagozzi et al. 1998). Hsu and Huang (2012) have made an extension of the theory of planned behavior model for tourists through SEM. Generally speaking, attitude entered the model as a mediating variable more frequently than as a dependent variable during the empirical analysis of the effect of the four variables on behavior intention in many studies There are some other variables such as self-efficiency(de Vries et al. 1988), but there is still a lack of empirical evidence. Chien et al. (2012) have conducted an explanatory attempting to examine the predictive power of TPB with the addition of past behavior and travel motivation in predicting behavioral intention of choosing a beach-based resort in Vietnam. This gives us a great hint that we can extend the model of TPB by importing new variables to improve the explanation of revisit intention.

As a typical kind of service, there is an important effect from the subjective experience of the tourists to the behavior intention and behavior itself. Therefore the consumption of tourism product is a complicated consuming process, in which the value evaluation of tourist plays an important role which affects the forming of behavior intention, and can be a mediating variable during the transition from attitude to behavior intention. On the contrast, the tourist's value and other factors are usually neglected in some degree. And this neglecting may lead to poor explanation to revisit intention. According to the research results, because of the limited variance of the three variables including attitude, subjective norm and Perceived behavioral control, it is not enough to rely solely on the traditional TPB to explain the real behavior intention. Han and Kim (2010) have made an investigation on green hotel customers' decision formation, and developed an extended model of the theory of planned behavior which can improve our understanding of the complicated process of green hotel customers' decision making. We theoretically need introduce other variables into the model to explain the remaining variance. So the TPB should be extended. 


\section{HYPOTHESES AND MODEL}

\section{A. Hypotheses}

Attitude is the predisposition to respond to a certain situation. Until now, there have been no strict empirical studies on the relation between attitude and behavior. Though many research results are not satisfactory, they do not completely and directly deny the relation between attitude and behavior. As a kind of psychological construction, attitude is durable and comparatively steady. To some extent,, it can influence and predict the production of behavior (Kraus 1995). Therefore, attitude can be regarded as the most important factor of behavior intention; it is the individual's active or negative evaluation of specific behavior. A consumer's behavior such as recommending or repurchasing is determined based on the attitude. If the attitude of behavior is active, the consumer will intend on this behavior, and if negative, he will not. In the research of consumption, there are many models of predicting behavior and behavior intention based on attitude. The research of Kim et al. (2004) proved that tourists' attitude of their destination's tourism culture would significantly affect their willingness to purchase souvenirs.. Ryu and Jang (2006) found that attitude is a significant predictor of tourist behavioral intentions. Lam and Hsu (2006) have also demonstrated that attitude is found to be related to behavioral intention of choosing a travel destination. Attitude can also be a mediate variable that Perceived behavioral control and Subjective Norm affect Behavior Intention from the angle of the relation between attitude and other variables. This is also demonstrated in other fields. Zhou and Peng (2006) studied consumers' purchasing willingness in the area of food safety, and the result demonstrates that the consumers' attitude of food safety affects their acceptance and furthermore their purchasing willingness. Therefore, despite the impact on travel intentions being unclear, according to various researchers, we can know that attitude is a distinguishable variable affecting travel intentions.

Therefore, the following hypothesis was formed:

Hypothesis 1: Attitude has significant influence on revisit intention, and it plays a mediating role during the influence from Subjective Norm, Perceived behavioral control and Past Behavior toward revisit intention.

Subjective Norm points to the social pressures that are exerted on an individual to perform or not to perform a specific behavior. Most of the work on tourist behavior intention is based on the Theory of Planned Behavior (TPB) model, which holds that behavioral intention is a consequence of attitude, subjective norm, and perceived behavioral control. Wang and Ritchie (2010) have conducted an empirical study on the relation between subjective norm and behavioral intention. Actually, subjective norm means that the actors would feel or endure pressure from some other important people or groups. In Theory of Reasoned Action, subjective norm is originally paratactic with attitude, and they both affect the behavior intention as dependent variables. But the later research demonstrated that both variables are interrelated. Many empirical studies found that subjective norm affects attitude significantly and directly (e.g. Titah and Barki 2009). Meanwhile, there is no significant effect of subjective norm on behavior intention which is not consistent with TPB. This is probably because part of subjective norm's influence is delivered by attitude as a mediating variable. There is a highlighted relation between subjective norm and revisit intention (Al Muala 2011). On the basis of the literature, we can make the conclusion that subjective norm has significant effect on both attitude and revisit intention whether the effect is direct or indirect.

Therefore, the following hypothesis was proposed:

Hypothesis 2: Subjective norm has significant effect on both attitude and revisit intention.

Perceived behavioral control plays an important part in the theory of planned behavior. In fact, TPB differs from the theory of reasoned action because of perceived behavioral control (Ajzen and Madden 1986). Perceived behavioral control refers to how easy or difficult an individual thinks it is to behave in a particular manner. It is assumed that perceived behavioral control is determined by the total set of accessible control beliefs, i.e., beliefs about the presence of factors that may facilitate or impede performance of the behavior. Specifically, the strength of each control belief is weighted by the perceived power of the control factor, and the products are aggregated. A conclusion was made after studying the undergraduates' attending intention of ecotourism that tourists' Perceived behavioral control together with attitude and subjective norm has significant active effect on behavior intention, and the effect is greater than that of subjective norm (Wu et al. 2003). Shen (2013) and Lam and Hsu (2006) have demonstrated that Perceived behavioral control is a valid predictor construct for visitors' intention to revisit. Similar conclusions have also been made by other scholars (e.g. Lai et al. 2010). On the basis of the above, perceived behavioral control and attitude are two of the most important factors affecting tourism behavior.

Therefore, the following hypothesis was proposed:

Hypothesis 3: Perceived behavioral control has significant influence on attitude and revisit intention.

Many scholars think that people always take actions by some way. Therefore, as long as this behavior occurred, the possibility of repeating the act is very large (Ouellette and Wood 1998), i.e., one kind of activity would not happen again if the result do not meet the actor's expectation. In this case, past behavior is one of the important factors. Therefore, past behavior can be a well-used tool to predict behavior intention and further behavior if we regard people's behavior as a consecutive sequence. Many empirical studies have proved past behavior's direct influence on behavior intention (e.g. Lam and Hsu 2006; Ryu and Jang 2006). Ferguson and Bibby (2002) studied the relation between the blood donor's past behavior and future intention of blood donating, and then make a conclusion that behavior intention can be predicted by accidental behaviors and past behaviors. Chien et al. (2012) has also demonstrated the relation between past behavior and behavioral intention. Furthermore, an inverted U-shaped curve relation exists between the past behavior and future behavior, especially for the regular blood donors. The experience of past travel behavior has considerable prediction on future leisure tourism for the same reason. Therefore past behavior has also the same influence on revisit intention. 
Therefore, the following hypothesis was proposed:

Hypothesis 4: Past behavior has significant influence on subjective norm, attitude and revisit intention.

Tourist value refers to the comparison of their gains and loss straightly. Gains refer to the total effectiveness oriented by the product or service, i.e., the happiness in spot scene, resource, service etc during the period of tourists' consuming. Loss refers to the total paying for the consuming including material, time, physical strength, energy etc. The research findings (e.g., Aarts et al. 1997; Yuexing 2002) demonstrated that customers' value has significant influence on the loyalty of customers which can be regarded as positive behavior intention. Wen (2013) studied each dimension of travelers' attitudes's influence on their purchase intentions and found that customer value is one of two valid variables measuring travelers' attitudes. Therefore, we can form such an opinion that tourist's value has significant influence on revisit intention.

Therefore, the following hypothesis was formed:

Hypothesis 5: Tourist's value has significant influence on revisit intention.

Destination image is commonly accepted as an important aspect in successful tourism management and destination marketing (Molina et al. 2010). Immovability of tourism product brought about that tourists cannot experience or tryout the product in person, which caused the tourism behavior including tourism product purchasing decision contains more risk and more information searching comparing with other consume behavior. Chew and Jahari (2014) found that the mediating role of destination image between perceived risks and revisit intention of repeat tourists to a risky destination through the study on the case of post-disaster Japan. Actually, perceived risk has relation with customer value as we know. As a result, decision of tourism behavior should be made on the basis of the psychological judgment to a great degree whether the tourism product can satisfy their requirements or not. In the research result of Regan et al. (2012), destination image is an important factors affecting group-oriented travel intention on major events, which is same as the research of Li et al. (2010). $\mathrm{Li}$ et al. have examined the relationships among destination image, travel motivation, and revisit intention in a rural tourism context through path analysis. The desire and trends of consumer's demand is determined by the images formed from the information of different channels. On this occasion, only such a kind of tourism destination can attract tourists which can arouse the good impression (Beerli and Martin 2004). Zhang et al. (2014) found that the impact of destination image on tourist loyalty is significant. Image of tourism destination plays an important role in stimulating the tourist's motivation. More and more researchers demonstrated that destination image is one of the most important factors (e.g., Crompton and Ankomah 1993; Baloglu and Brinberg 1997; Baloglu and Mangaloglu 2001; Tavitiyaman and Qu 2013).

Therefore, the following hypothesis was proposed:

Hypothesis 6: Destination image has significant influence on tourist's value and revisit intention.
According to the Theory of Planned Behavior, attitude is formed after the conceptualization of individual's evaluation on some behavior, so it can be regarded as the function of the individual's belief on the result of some behavior. Under the construction of expectancy-value theory, attitude can be expressed as the product of individual's beliefs leading from the behavior's result. From the perspective of Customer Value Theory, customer value is the comparing result between the gain and loss. In many researches, customer value is usually appearing as the gap between expected value and actual value (Blocker et al. 2011;Flint et al. 2011). Factors of gains included product, service, promotion etc, factors of loss comprised price mainly except other cost paid by customers (Lin 2000). Zins (2001)has already found there is a relation between attitude and customer value. It can be drawn that there is a close relationship between the factors of tourist value and tourist's feeling. That's to say, the subjective judgment significantly influence tourist value. According to the researching, the tourist's subjective judgment is formed based on the experience and individual need, which is connected with tourist's behavior belief beyond all questions.

Therefore, the following two hypotheses were proposed:

Hypothesis 7: Attitude has significant influence on tourist value.

Hypothesis 8: Tourist value is a mediating variable during the process of attitude's influencing revisit intention

\section{B. Model Construction}

Based on the above analysis, we can set up the relation among different variables and construct the extended model of formation mechanism of revisit intention based on the Theory of Planned Behavior.

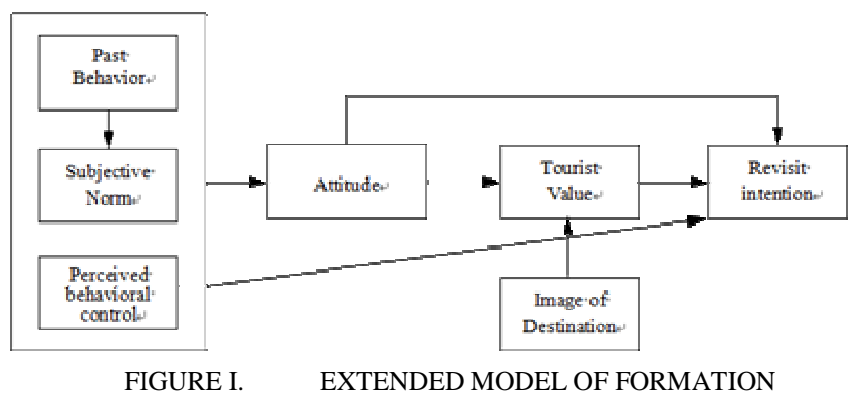

FIGURE I. EXTENDED MODEL OF FORMATION

III. METHOD

\section{A. Survey}

All variables are measured by 5 points Likert-type rating scale besides past behavior. In order to ensure the respondents' proper understanding of the survey, we had made a trial investigation in order to revise the survey based on the analysis of problems that respondent have reported. Eventually the formal survey consisting of 46 items is formed. Subjective norm is measured by 8 items, i.e., your family or important persons support you to have a travel etc. Attitude is measured by 7 items, i.e., leisure tourism can improve your social growth, taking part in leisure tourism activities can support you chance to know new friends etc. Perceived behavioral control is 
measured by 4 items, i.e., you have enough money to have a travel etc. Tourist value is measured by 18 items, i.e., you think the traditional folk-custom of this destination is very good etc. Destination image is measured by 8 items including the tourists' impression of local service facilities, tourism traffic, cultural scene-spot, living facilities, leisure circumstance, citizen's attitude of tourists and service quality. Past behavior is measured by the asking the tourists for times directory. Revisit intention is measured by 3 items including revisiting by oneself, buying on rich premium and recommend to other one.

\section{B. Survey and Data Collection}

An empirical study was conducted to test the proposed model and hypotheses. According to the characteristics of sightseeing tourism market, we divided the samples into 3 parts including package tourists, semi-package tourists and individual tourists. Package tourist is who paid his entire travel fee by travel agency, individual tourist pays it by himself, and semi-package tourist paid part travel fees by travel agency and part by himself. Taking account of the amount and efficiency of the survey, we distribute 1200 questionnaire copies including 600 package tourist samples, 300 semi-package tourist samples and 300 individual tourist samples.

In order to get overall data, we made the survey through random sampling method in Dongqian Lake resort, Songlan Mountain resort, Siming Mountain Forest Garden and Ninghai Leisure Tourism Base. These resorts are typical destinations of lake, seaside, mountain and metropolis in Ningbo city. According to the statistics and documents of Ningbo Tourism Administrative Bureau, these four sorts of destination have their own characteristics and represent different types of destination of lake, sea, mountain and field whose images are easily to perceive. Tourists of different destinations usually have different objects. Samples in these four resorts can stand for which of the whole Ningbo city. As for Ningbo, she is a commercial city in which tourism industry developed very quickly in recent years. And Ningbo is a typical city of tourism industry development in East China that was named one of China's top ten leisure cities in 2011.

The data used in this study was collected through a selfadministrated survey which was distributed following a process in which about 20 students and staff from Ningbo Institute of Technology were given copies of the survey at different spots. The students and staff were divided into 4 groups that there is one teacher in each group. The group would select a spot where most tourists would exit after completing the whole sightseeing. Then the group would hand in the survey copy and one gift to each sample in order to make the sample filling out the survey carefully, each subject was asked to fill out one. Firstly, the group would explain the way of filling out orally, and then they would wait for it near the sample. When the sample completed, the group would take back the survey as soon as possible.

\section{Sample Profile}

We have completed 1200 surveys and taken 1072 back. Finally, there are altogether 946 valid surveys. The socialdemographic profile of tourist samples is as following:
TABLE I. SOCIO-DEMOGRAPHIC PROFILE OF TOURIST SAMPLES

\begin{tabular}{|l|l|c|c|}
\hline \multicolumn{1}{|c|}{$\begin{array}{c}\text { Demographic } \\
\text { variable }\end{array}$} & \multicolumn{1}{|c|}{ Item } & Number & $\begin{array}{c}\text { Percentage } \\
(\%)\end{array}$ \\
\hline \multirow{3}{*}{ Sex } & Male & 503 & 53.17 \\
\cline { 2 - 4 } & Female & 443 & 46.83 \\
\hline \multirow{5}{*}{ Age } & $<18$ & 45 & 4.76 \\
\cline { 2 - 4 } & $18-25$ & 409 & 43.23 \\
\cline { 2 - 4 } & $26-40$ & 319 & 33.72 \\
\cline { 2 - 4 } & $41-60$ & 125 & 13.21 \\
\cline { 2 - 4 } & $>61$ & 48 & 5.07 \\
\hline Education & Left high school before & 111 & 11.73 \\
\cline { 2 - 4 } & Earned a high school & 208 & 21.99 \\
\cline { 2 - 4 } & Associate degree & 392 & 41.44 \\
\cline { 2 - 4 } & Bachelor's degree & 208 & 21.99 \\
\cline { 2 - 4 } & Master's degree & 23 & 2.43 \\
\hline Types & Package tourist & 473 & 50.00 \\
\cline { 2 - 4 } & Semi-package tourist & 166 & 17.55 \\
\cline { 2 - 4 } & Individual tourist & 307 & 32.45 \\
\hline Total & & 946 & 100 \\
\hline \multirow{2}{*}{} & & & \\
\hline
\end{tabular}

\section{DATA ANALYSIS}

\section{A. Data Analysis}

In order to know whether different characteristic tourist samples have variance on different variables and evaluate the construct validity respectively, we made variance analysis and confirmatory factor analysis firstly. The result of variance analysis demonstrated that there is no significant variance between samples with different education, different salary and different profession. The fit index of confirmatory factor analysis model demonstrated that the construct validity of confirmatory factor analysis of the variables can be accepted.

In the research field, many scholars have ever applied structural equation model to study (e.g. Han and Kim 2010; Li et al. 2010; Assaker et al. 2011;Al Muala 2011;Regan et al. 2012; Chien et al. 2012). The proposed model was tested in AMOS 5.0 using SEM methodologies to investigate the effects of the variables on revisit intention. We also used AMOS 5.0 to analyze the fundamental structural model of tourism behavior formation mechanism. The goodness-of-fit of the structural equation model is as following:

TABLE II. GOODNESS-OF-FIT MEASURES FOR THE ORIGINAL MODEL

\begin{tabular}{|c|c|c|c|c|c|c|c|c|c|}
\hline $\begin{array}{c}\text { Fit } \\
\text { inde } \\
\mathbf{x}\end{array}$ & $\begin{array}{c}\text { Degree } \\
\text { of } \\
\text { freedom }\end{array}$ & $\boldsymbol{\chi 2}$ & $\mathbf{P}$ & $\boldsymbol{\chi} \mathbf{2} / \mathbf{d f}$ & $\mathbf{N F I}$ & $\mathbf{C F I}$ & $\mathbf{I F I}$ & $\mathbf{R F I}$ & $\begin{array}{c}\text { RMS } \\
\text { EA }\end{array}$ \\
\hline Value & 156 & 314626 & 0.00 & 20.168 & 0.879 & 0.910 & 0.921 & 0.838 & 0.237 \\
\hline
\end{tabular}


TABLE III. PATH ANALYSIS (N=946)

\begin{tabular}{|c|c|c|c|c|c|}
\hline & & $\begin{array}{l}\text { Standardized } \\
\text { regression } \\
\text { coefficients }\end{array}$ & $\begin{array}{l}\text { Standard } \\
\text { Variance }\end{array}$ & C.R. & Sig. \\
\hline \begin{tabular}{|l|} 
Tourist \\
Value
\end{tabular} & $\leftarrow$ Attitude & .322 & .011 & 30.203 & $* * *$ \\
\hline $\begin{array}{l}\text { Revisit } \\
\text { Intention }\end{array}$ & $\leftarrow$ Attitude & -.080 & .023 & -3.463 & $* * *$ \\
\hline $\begin{array}{l}\text { Revisit } \\
\text { Intention }\end{array}$ & $\leftarrow$ Tourist Value & .271 & .063 & 4.335 & $* * *$ \\
\hline Attitude & $\leftarrow$ Past Behavior & .726 & .035 & 29.003 & $* * *$ \\
\hline $\begin{array}{l}\text { Subjective } \\
\text { Norm }\end{array}$ & $\leftarrow$ Past Behavior & .584 & .042 & 14.010 & $* * *$ \\
\hline Attitude & $\leftarrow$ Subjective Norm & .855 & .046 & 26.103 & $* * *$ \\
\hline Attitude & $\leftarrow \begin{array}{l}\text { Perceived } \\
\text { behavioral control }\end{array}$ & .620 & .041 & 25.168 & $* * *$ \\
\hline
\end{tabular}

Note. $* * * p<0.01$

In tab.2, degree of freedom is $156, \chi^{2}$ is $3146.267, \chi 2 / \mathrm{df}$ is 20.168, which is greater than 5, for other index, NFI is 0.879, CFI is 0.910 ,IFI is 0.921 , RFI is 0.838 ,they are all less than 0.9 which is the standard whether the model can be accepted or not. And also, RMSEA is 0.237 which is greater than 0.08 .

There are many reasons probably for the unfitting of the initial model. We can analyze it from the fact of this research. The reasons are probably as following:

1. The variance of behavior intention explained by attitude is less. According to many empirical study results, the variance of behavior intention explained by attitude cannot usually attain a satisfying result. Even if there is a significant relation between attitude and behavior intention, the fitting degree of the structural equation model would not be good if the variance explained is not high.

2. Past behavior has a significant influence on subjective norm. Subjective norm represents a kind of outside pressure when the behavior subject takes some activity. And also, this pressure appeared as a function of individual's normative belief and motivation. As we know, individual's normative belief and motivation is influenced deeply by past behavior, but this relation has not been acknowledged in the past research. It is supposed that the relation between past behavior and subjective norm is existed during the conforming process of revisit intention.

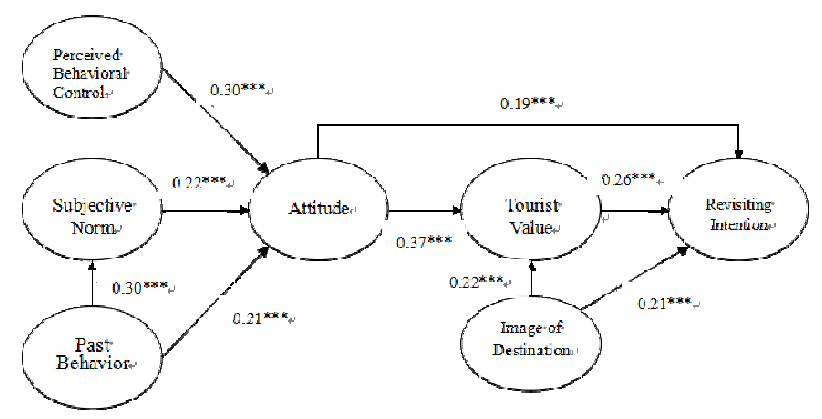

FIGURE II.

REVISED SEM METPB OF REVISIT INTENTION FORMATION MECHANISM

In order to secure for better fitting during the analyzing, we improved the structural equation model partly. We found that the fitting of new model is better than other revised model if we set a relation between pair variable of past behavior and subjective norm, subjective norm and behavior intention which is as following:

The goodness-of-fit of the structural equation model are as following:

\begin{tabular}{|c|c|c|c|c|c|c|c|c|c|}
\hline TABLE IV. & \multicolumn{1}{|c|}{ GOODNESS-OF-FIT OF SEM METPB OF REVISIT INTENTION } \\
\begin{tabular}{|c|c|c|c|c|c|} 
Fit \\
inde \\
$\mathbf{x}$
\end{tabular} & $\begin{array}{c}\text { Degree } \\
\text { of } \\
\text { freedom }\end{array}$ & $\boldsymbol{\chi} \mathbf{2}$ & $\mathbf{P}$ & $\boldsymbol{\chi} \mathbf{2} / \mathbf{d f}$ & $\mathbf{N F I}$ & $\mathbf{C F I}$ & $\mathbf{I F I}$ & $\mathbf{R F I}$ & $\begin{array}{c}\text { RMS } \\
\mathbf{E A}\end{array}$ \\
\hline Value & 162 & 748.37 & 0.00 & 4.619 & 0.900 & 0.912 & 0.918 & 0.908 & 0.150 \\
\hline
\end{tabular}

In tab.3,even RMSEA is 0.150 which is a little greater than 0.08 , but for other fitting indexes, degree of freedom is $162, \chi^{2}$ is $748.370, \chi^{2 / \mathrm{df}}$ is 4.619 which is less than $5, \mathrm{NFI}$ is 0.900 , CFI is 0.912 , IFI is 0.918 , RFI is 0.908 ,all of them are greater than 0.9. This demonstrated that the fitness of METPB is high, and METPB can explain the forming mechanism of revisit intention better.

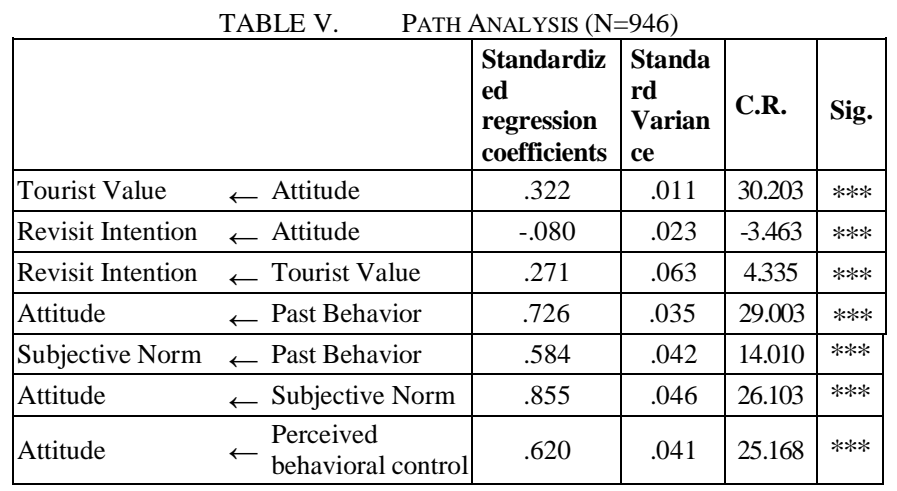

Note. $* * * p<0.01$

\section{B. Hypotheses Testing Result}

According to the testing result of structural equation model, the result is as following:

TABLE VI. RESULT OF HYPOTHESIS VERIFICATION

\begin{tabular}{|l|l|}
\hline \multicolumn{1}{|c|}{ Hypotheses } & Result \\
\hline $\begin{array}{l}\text { Hypotheses 1: Attitude has significant influence on revisit } \\
\text { intention, and it plays a mediating role during the influence from } \\
\text { Subjective Norm, Perceived behavioral control and Past } \\
\text { Behavior toward revisit intention. }\end{array}$ & Supported \\
\hline $\begin{array}{l}\text { Hypotheses1a: Attitude has significant influence on revisit } \\
\text { intention. }\end{array}$ & Supported \\
\hline $\begin{array}{l}\text { Hypotheses 1b: Subjective norm has significant influence on } \\
\text { attitude. }\end{array}$ & Supported \\
\hline $\begin{array}{l}\text { Hypotheses 1c: Perceived behavioral control has significant } \\
\text { influence on attitude. }\end{array}$ & Supported \\
\hline $\begin{array}{l}\text { Hypotheses 1d: Past behavior has significant influence on } \\
\text { attitude. }\end{array}$ & Supported \\
\hline $\begin{array}{l}\text { Hypotheses 2: Subjective norm has significant effect on both } \\
\text { attitude and revisit intention. }\end{array}$ & $\begin{array}{l}\text { Partly } \\
\text { Supported }\end{array}$ \\
\hline $\begin{array}{l}\text { Hypotheses 2a: Subjective norm has significant influence on } \\
\text { attitude. }\end{array}$ & Supported \\
\hline $\begin{array}{l}\text { Hypotheses 2b: Subjective norm has significant influence on } \\
\text { revisit intention. }\end{array}$ & Rejected \\
\hline $\begin{array}{l}\text { Hypotheses 3: Perceived behavioral control has significant } \\
\text { influence on attitude and revisit intention. }\end{array}$ & $\begin{array}{l}\text { Partly } \\
\text { Supported }\end{array}$ \\
\hline $\begin{array}{l}\text { Hypotheses 3a: Perceived behavioral control has significant } \\
\text { influence on attitude. }\end{array}$ & Supported \\
\hline
\end{tabular}




\begin{tabular}{|l|l|}
\hline $\begin{array}{l}\text { Hypotheses 3b: Perceived behavioral control has significant } \\
\text { influence on revisit intention. }\end{array}$ & Rejected \\
\hline $\begin{array}{l}\text { Hypotheses 4: Past behavior has significant influence on } \\
\text { subjective norm, attitude and revisit intention. }\end{array}$ & $\begin{array}{l}\text { Partly } \\
\text { Supported }\end{array}$ \\
\hline $\begin{array}{l}\text { Hypotheses 4a: Past behavior has significant influence on } \\
\text { subjective. norm. }\end{array}$ & Rejected \\
\hline $\begin{array}{l}\text { Hypotheses 4b: Past behavior has significant influence on } \\
\text { attitude. }\end{array}$ & Supported \\
\hline $\begin{array}{l}\text { Hypotheses 4c: Past behavior has significant influence on revisit } \\
\text { intention. }\end{array}$ & Rejected \\
\hline $\begin{array}{l}\text { Hypotheses 5: Tourist's value has significant influence on revisit } \\
\text { intention. }\end{array}$ & Supported \\
\hline $\begin{array}{l}\text { Hypotheses 6: Destination image has significant influence on } \\
\text { tourist' s value and revisit intention. }\end{array}$ & Supported \\
\hline $\begin{array}{l}\text { Hypotheses 6a: Destination image has significant influence on } \\
\text { tourist's value. }\end{array}$ & Supported \\
\hline $\begin{array}{l}\text { Hypotheses 6b: Destination image has significant influence on } \\
\text { revisit intention. }\end{array}$ & Supported \\
\hline $\begin{array}{l}\text { Hypotheses 7: Attitude has significant influence on tourist's } \\
\text { value. }\end{array}$ & Supported \\
\hline $\begin{array}{l}\text { Hypotheses 8:Tourist value is a mediate variable during the } \\
\text { process of attitude' s influencing revisit intention }\end{array}$ & Supported \\
\hline $\begin{array}{l}\text { Hypotheses 8a: Attitude has significant influence on tourist's } \\
\text { value. }\end{array}$ & Supported \\
\hline $\begin{array}{l}\text { Hypotheses 8b: Tourist value has significant influence on revisit } \\
\text { intention. }\end{array}$ & Supported \\
\hline
\end{tabular}

\section{RESULT}

\section{A. Revisit Intention is Influenced Directly by Many Variables}

Our empirical study demonstrated that revisit intention is influenced directly by attitude, Perceived behavioral control, destination image which is accordingly with the theoretical analysis in the front of this article. At the same time, we have also tested that both subjective norm and tourist value both influence revisit intention significantly which is not accordingly with other research results in the past. The results demonstrated that subjective norm has no significant influence on behavior intention (Hua-min 2010). The result of this article demonstrated that subjective norm's importance during the forming of revisit intention is because the ultimate object of leisure tourism is to gain a psychological perceiving. From this angel, individual's internal norm and society's outside importance are both important, they and attitude and Perceived behavioral control altogether have significant influence on revisit intention.

After customer value was introduced to the models of studying consumer behavior and behavior interest as a variable, researchers have not formed a unified opinion about the position of which. The result of this essay demonstrated that tourist value influence revisit intention significantly. Higher the tourist value, more the revisit intention. This is related with the characteristics of tourism product as service, because the service products are all intangible, and the quality is judged by the subjective feeling of tourists. And tourist value is the direct result of this judgment. Especially for the tourism, locality is an important character. The potential tourists are generally arising their needs in pursuit of relaxing their pressure. This is depends on the value judgment and experience of past travel behavior. Therefore, in addition to attitude, subjective norm and Perceived behavioral control have direct and indirect influence; tourist value and past behavior are also the important factors on revisit intention.

\section{B. Attitude and Tourist Value are Both Important Mediate Variables to Discover Revisit Intention Forming Mechanism}

This essay demonstrated that attitude is the mediate variable during the process of subjective norm, Perceived behavioral control and past behavior influencing revisit intention, tourist value is mediate variable during which of attitude.

In relative researches, attitude was usually regarded as a wholly independent variable to influence behavior intention, and the explanatory power cannot be improved under this research construction. Through this research, tourist value is an important mediate variable during the influencing process from attitude to revisit intention. The explanation of the model can be improved by bringing this mediate variable into. In the formation mechanism of revisit intention, subjective norm, Perceived behavioral control are both influence attitude significantly, and also influence revisit intention through attitude. More active the subjective norm, Perceived behavioral control and past behavior, more active the attitude.

Tourist value plays some mediating role during the influencing process from attitude to revisit intention. In order to facilitate for tourists to co create experience value then, not only should the industry recognize experiences that tourists value but should also acknowledge motivation and involvement as essential in value creation for tourist experiences (Chien et al. 2012). Attitude and tourist value link subjective norm, Perceived behavioral control, past behavior and image of tourism destination together. All the variables interact and impact on revisit intention. This research demonstrated that tourist value is a good variable whose existence can not only explain some variance from attitude to behavior intention, but also transmit other variables' influence on revisit intention. This result is accordingly with such an opinion that some new variables should be added into model of TPB in order to improve the explanation (Armitage and Conner 2001).

\section{METPB Improved the Explanation of Forming \\ Mechanism of Revisit intention}

Though people usually think Theory of Planned Behavior is a kind of process theory because it put the emphasis on the process of behavior or behavior intention's formation. On the contrary, Customer Value Theory is a kind of comparative theory because it put the emphasis on the compare between cost and benefit of the purchasing. But we can still find the interaction between Theory of Planned Behavior and Customer Value Theory and construct the model of METPB. Customer value is determined by individual's preference, at the same time the individual's preference is determined by the attitude. So it is natural to set up relation between attitude and customer value (Blackwell et al. 1999). This viewpoint has been tested in this essay adequately. This result originated from the integration of Theory of Planned Behavior and Customer Value Theory that caused the METPB can not only explain the process of behavior intention forming but also express the decision-making gist before the revisit intention was formed.

\section{ACKNOWLEDGMENT}

This research has been supported by a grant from Zhejiang Provincial Natural Science Funding (Y12G020095) and Zhejiang Provincial Soft science Funding (2013C35088). 


\section{REFERENCES}

[1] Aarts, H., B. Verplanken, and A. Van Knippenberg Habit and information use in travel mode choices. Acta Psychological vol. 96(1), 1997, pp. 1-14.

[2] Ajzen, I., and B.L. Driver Application of the theory of planned behavior to leisure choice. Journal of leisure research. vol. 24(3) ,1992, pp. 207-224.

[3] Ajzen, I., and T.J. Madden Prediction of goal-directed behavior: Attitudes, intentions, and perceived behavioral control. Journal of experimental social psychology vol. 22(5), 1986, pp. 453-474.

[4] Al Muala, A.M. Antecedents of Actual Visit Behavior amongst International Tourists in Jordan: Structural Equation Modeling (SEM) Approach. American Academic \& Scholarly Research Journal (AASRJ) vol. 1(1), 2011, pp. 35-42.

[5] Armitage, C.J., and M. Conner Efficacy of the theory of planned behaviour: A meta - analytic review. British journal of social psychology vol. 40(4), 2001, pp. 471-499.

[6] Assaker, G., V.E. Vinzi, and P. O Connor Examining the effect of novelty seeking, satisfaction, and destination image on tourists' return pattern: A two factor, non-linear latent growth model. Tourism Management vol. 32(4), 2011, pp. 890-901.

[7] Bagozzi, R.P., Y. Yi, and K.D. Nassen Representation of measurement error in marketing variables: Review of approaches and extension to three-facet designs. Journal Of Econometrics vol. 89(1), 1998, pp. 393421.

[8] Baloglu, S., and D. Brinberg Affective images of tourism destinations. Journal of travel research vol. 35(4), 1997, pp. 11-15.

[9] Baloglu, S., and M. Mangaloglu Tourism destination images of Turkey, Egypt, Greece, and Italy as perceived by US-based tour operators and travel agents. Tourism management vol. 22(1), 2001, pp. 1-9.

[10] Beerli, A., and J.D. Martin Factors influencing destination image. Annals of tourism research vol. 31(3), 2004, pp. 657-681.

[11] Blackwell, S.A., S.L. Szeinbach, J.H. Barnes, D.W. Garner, and V. Bush The Antecedents of Customer Loyalty An Empirical Investigation of the Role of Personal and Situational Aspects on Repurchase Decisions. Journal of Service Research vol. 1(4), 1999, pp. 362-375.

[12] Blocker, C.P., D.J. Flint, M.B. Myers, and S.F. Slater Proactive customer orientation and its role for creating customer value in global markets. Journal of the Academy of Marketing Science vol. 39(2), 2011, pp. 216-233.

[13] Chew, E.Y.T., and S.A. Jahari Destination image as a mediator between perceived risks and revisit intention: A case of post-disaster Japan. Tourism Management vol. 40(1), 2014, pp. 382-393.

[14] Chien, G.C., I. Yen, and P. Hoang Combination of theory of planned behavior and motivation: An exploratory study of potential beach-based resorts in Vietnam. Asia Pacific Journal of Tourism Research vol. 17(5), 2012, pp. 489-508.

[15] Crompton, J.L., and P.K. Ankomah Choice set propositions in destination decisions. Annals of Tourism Research vol. 20(3), 1993, pp. 461-476.

[16] de Vries, H., M. Dijkstra, and P. Kuhlman Self-efficacy: the third factor besides attitude and subjective norm as a predictor of behavioural intentions. Health education research vol. 3(3), 1988, pp. 273-282.

[17] Feng, R. Temporal destination revisit intention: The effects of novelty seeking and satisfaction. Tourism management vol. 28(2), 2007, pp. 580590.

[18] Ferguson, E., and P.A. Bibby Predicting future blood donor returns: Past behavior, intentions, and observer effects. Health Psychology vol. 21(4),2002, pp. 513.

[19] Flint, D.J., C.P. Blocker, and P.J. Boutin Customer value anticipation, customer satisfaction and loyalty: An empirical examination. Industrial Marketing Management vol. 40(2),2011, pp. 219-230.

[20] Han, H., and Y. Kim An investigation of green hotel customers' decision formation: Developing an extended model of the theory of planned behavior. International Journal of Hospitality Management vol. 29(4), 2010, pp. 659-668.

[21] Hsu, C.H., and S.S. Huang An extension of the theory of planned behavior model for tourists. Journal of Hospitality \& Tourism Research vol. 36(3), 2012, pp. 390-417.

[22] Hua-min, LI. A study on the formation mechanism of tourism destination choosing intention based on the customer value theory. Geographical Research vol. 29(7), 2010, pp. 1335-1344.

[23] KERNER, M.S., and M.I. KALINSKI SCALE CONSTRUCTION FOR MEASURING ADOLESCENT BOYS'AND GIRLS'ATTITUDES, BELIEFS, PERCEPTION OF CONTROL, AND INTENTION TO ENGAGE IN LEISURE-TIME PHYSICAL ACTIVITY. Perceptual and motor skills vol. 95(1), 2002, pp. 109-117.

[24] Kim, M., M. Park, and D. Jeong The effects of customer satisfaction and switching barrier on customer loyalty in Korean mobile telecommunication services. Telecommunications Policy vol. 28(2), 2004, pp. $145-159$.

[25] Kraus, S.J. Attitudes and the prediction of behavior: A meta-analysis of the empirical literature. Personality and social psychology bulletin vol. 21(1), 1995, pp. 58-75.

[26] Lai, C., T. Yu, and J. Kuo How to say sorry: Increasing revisit intention through effective service recovery in theme parks. Social Behavior and Personality: an international journal vol. 38(4), 2010, pp. 509-514.

[27] Lam, T., and C.H. Hsu Predicting behavioral intention of choosing a travel destination. Tourism Management vol. 27(4), 2006, pp. 589-599.

[28] Li, M., L.A. Cai, X.Y. Lehto, and J. Huang A missing link in understanding revisit intention-The role of motivation and image. Journal of Travel \& Tourism Marketing vol. 27(4), 2010, pp. 335-348.

[29] Lin, B. Marketing strategy analysis of individual tourists in China. Commercial Study. vol. 25(6), 2000, pp. 81-83.

[30] Molina, A., M. Gómez, and D. Martín-Consuegra Tourism marketing information and destination image management. African Journal of Business Management vol. 4(5), 2010, pp. 722-728.

[31] Ouellette, J.A., and W. Wood Habit and intention in everyday life: the multiple processes by which past behavior predicts future behavior. Psychological Bulletin vol. 124(1), 1998, pp. 54.

[32] Regan, N., J. Carlson, and P.J. Rosenberger III Factors affecting grouporiented travel intention to major events. Journal of Travel \& Tourism Marketing vol. 29(2), 2012,pp. 185-204.

[33] Ryu, K., and S.S. Jang Intention to experience local cuisine in a travel destination: The modified theory of reasoned action. Journal of Hospitality \& Tourism Research vol. 30(4), 2006, pp. 507-516.

[34] Shen, S. Intention to Revisit Traditional Folk Events: A Case Study of Qinhuai Lantern Festival, China. International Journal of Tourism Research. vol. 22(3), 2013, pp. 208-216.

[35] Tavitiyaman, P., and H. Qu Destination Image and Behavior Intention of Travelers to Thailand: the Moderating Effect of Perceived Risk. Journal of Travel \& Tourism Marketing vol. 30(3), 2013, pp. 169-185.

[36] Titah, R., and H. Barki Nonlinearities between attitude and subjective norms in information technology acceptance: a negative synergy? Mis Quarterly vol. 33(4),2009, pp. 827-844.

[37] Wang, J., and B.W. Ritchie A theoretical model for strategic crisis planning: factors influencing crisis planning in the hotel industry. International Journal of Tourism Policy vol. 3(4),2010, pp. 297-317.

[38] Wen, I. Online Shopping of Travel Products: A Study of Influence of Each Dimension of travelers' Attitudes and the Impact of travelers' Online Shopping Experiences on Their Purchase Intentions. International Journal of Hospitality \& Tourism Administration vol. 14(2),2013, pp. 203-232.

[39] Wu, Z., L. Fan, and P. Su Relative study of undergraduates' intention of participating ecotourism. Research of Environment and Management. vol. 23(1), 2003, pp. 1-28.

[40] Yingheng Zhou, X.P. Consumer Willingness to Pay for Food Safety in Jiangsu Province China:A Case Study of Reduced Pesticide Residues B.Chinensis. China Economic Quarterly. vol. 5(3), 2006, pp. 1319-1342.

[41] Yuexing, W. The Drivers of Customer Loyalty and their Function. Journal of Shandong University. vol., 25(4),2002, pp. 103-107.

[42] Zhang, H., X. Fu, L.A. Cai, and L. Lu 2014 Destination image and tourist loyalty: A meta-analysis. Tourism Management vol. 40(1), 2014, pp. 213-223.

[43] Zins, A.H. Relative attitudes and commitment in customer loyalty models: some experiences in the commercial airline industry. International Journal of Service Industry Management vol. 12(3),2001, pp. 269-294. 